\title{
ARTIKELEN
}

\section{Kuhn and Legal Research}

\section{A Reflexive Paradigmatic View on Legal Research*}

\author{
Ubaldus de Vries
}

\section{Introduction}

The phrase 'legal paradigm' is used in the literature to describe a particular state of affairs in respect of a particular issue subject to legal regulation. Usually, the prevailing legal paradigm on that issue is criticized and arguments are advanced in order to initiate a paradigm shift. This shift, the formulation of a new paradigm, is perceived as revolutionary because it demands letting go of wellestablished assumptions about the law and how it regulates the issue at hand. ${ }^{1}$ Another way the notion is used is to describe the evolution of the body of law on a particular novel theme, such as biotechnology and personhood, sports and doping, etc. ${ }^{2}$

This reliance on 'paradigm' as a means to embed legal research emulates the scientific method as described by Thomas Kuhn (1996) in his The Structure of Scientific Revolutions. However, it only does so in part. In this article, I propose that an elementary understanding of the Kuhnian structure of scientific research is useful in understanding modern legal research. The approach is, first, aimed at making more explicit how the thought processes underlining the Kuhnian structure could be useful for a better understanding of modern legal research. This is a worthwhile exercise in itself. It demands a brief analysis of the core ideas of The Structure, such as the meaning of paradigm, the distinction between 'normal' and 'revolutionary' science, the processes of professionalization and how students come to understand the scientific paradigm, and how revolutionary changes in thought are coming about through a reflexive attitude towards developments that fit ill in the existing paradigm - so called anomalies.

It permits, second, the description of 'normal legal research', which revolves around the conflict-resolving potential of modern law. The frame of reference of normal legal research is based on certain assumptions about law itself, its func-

* I am grateful to Bart van Klink, Lyana Francot, David Nelken, René Brouwer and Marjolein van der Brink for their helpful comments and suggestions. Part of this article has been presented at the Critical Legal Conference, 10-12 September 2010, Utrecht, The Netherlands.

1 An example is intimacy and how it is/ought to be regulated; see Cohen 2002.

2 See, respectively, <http://ieet.org/index.php/IEET/more/406/> (bio-technology and personhood); 〈http://findarticles.com/p/articles/mi_m2ABX/is_3-4/ai_n25012285> (sports and doping). (Sites last accessed 15 January 2013.) 
tion and the problems it addresses. These are context-bound; they are shaped by society and, moreover, these assumptions remain implicit. They are not explained in the study of law, taken as a given instead. A first step, then, to sketch a paradigmatic picture of legal research is to make these assumptions, and where they come from, explicit. This demands, in my view, the introduction of social theory. Recourse to social theory helps in explaining the context of modern law theoretically and at the level of society (rather than at the level of societal incidents or events). In this article, I rely on the theory of reflexive modernization as developed by the German social theorist Ulrich Beck. The point is to illustrate the usefulness of social theory in the paradigmatic sketch. I do not propose that there necessarily is a legal research paradigm. Rather, the thought processes behind paradigmatic thinking may help describing better what we do as researchers, and not do.

\section{2 'The Structure of Scientific Revolutions'}

Kuhn describes in The Structure two processes of scientific endeavour, deviating from the traditional view that seeks to explain the activity of science as an 'incremental process' (Kuhn 1996, p. 2). ${ }^{3}$ The first process, which Kuhn refers to as 'normal science', is the scientific activity within an established paradigm. From within such a paradigm revolutions occur where and when new ideas make old ideas obsolete. Although Kuhn's work is well-known and analysed (Fuller 2003; Preston 2008), reference in legal practice and research is usually limited to the notion of 'paradigm' and not to change and how change in thought comes about (Cotterrell 1995, p. 41-72; Wallace 1978; Campbell 1974).

\subsection{Paradigms}

A scientific paradigm, according to Kuhn, suggests a consensus about assumptions, which enables the formulation of a problem as well as developing arguments and solutions in respect of the problem. A paradigm refers to: 'an entire constellation of beliefs, values and techniques, and so on, shared by the members of a given community' (Kuhn 1996, p. 175). ${ }^{4}$ A paradigm represents the body of knowledge and allows scientists to work with the body of knowledge in order to make truth claims. It offers theoretical and practical tools. It determines what is to be observed and made subject of scientific study. In doing so, it excludes other possibilities. Hence, a paradigm constitutes a pre-selection, defining the scientist's playground so to speak, in terms of consolidated scientific expectations. It follows that the paradigm is informative about the type of research questions and how these questions must be formulated in order to generate answers from

3 Preston (2008, p. 12, 52) refers to the traditionally believed mode of 'cumulativism'.

4 This is one of the two meanings he attributes to the scientific paradigm, as written in his Postscript to the second edition (1996, p. 174). Indeed, 'paradigm' remains an ambiguous term and Kuhn later preferred to refer to 'exemplar' to delineate the narrow meaning of paradigm from the broader meaning, which he referred to as a 'disciplinary matrix' (1996, p. 187, 182). See also Cotterrell 1995, p. 45. In this article, I hold on to the term paradigm. 
within the paradigm. It also enables how the results of scientific investigations - the answers - should be interpreted. In short, a paradigm entails the tools of observation, analysis, argumentation and interpretation in respect of a particular body of knowledge vis-à-vis its domain of analysis.

\section{2 'Normal science'}

Within an established paradigm, scientists engage in what Kuhn refers to as 'normal science' (Kuhn 1996, p. 10). These achievements form the basis for the emergence of the initial paradigm when they are sufficiently (1) unprecedented to attract an enduring group of adherents away from competing ones and (2) openended enough to leave problems for the redefined group to resolve. Kuhn stresses that there is an element of arbitrariness in this process as it pertains to the interpretation of facts, and interpretation cannot exist without some (implicit) body of intertwined theoretical and methodological beliefs. In the end, the emergence of the paradigm allows for the institutionalization of beliefs, values and techniques. While firmly remaining within the box, the scientists can engage in in-depth analysis of well-defined problems that would be inconceivable in the absence of the paradigm.

\subsection{Initiation}

The community of scientists that engage in research by reference to a particular paradigm, Kuhn suggests, forms a specialization in the field of science, allowing for disciplinary institutionalization. So, paradigmatic structures enable monopolization which is further strengthened by processes of (professional) institutionalization and ritualization.

The point is that a striking feature of normal science lies in the process of initiation of new members. This process is also ritualized and preserves the hegemony or monopoly of the research community. New members are initiated to the paradigm without express knowledge of it. The essential features of the paradigm - beliefs, values and techniques - are taught, according to Kuhn (1996, p. 47), unreflective. The mode of doing so is through the study of textbooks. Their essential feature is that they expound upon the body of accepted theory, illustrate its successful application and compare these with exemplary observations and experiments. There is no need to know the characteristics that gave it the status of the community's paradigm. It is taken for granted.

An implication is that revolutions remain invisible, which, to Kuhn (1996, p. 137), truncates 'the scientist's sense of his discipline's history [supplying] a substitute for what they have eliminated'. There exists a, to follow Taylor's model of representation (2004, p. 23), a particular social imaginary about what science is: 'science has reached its present state by a series of individual discoveries and inventions that, when gathered together, constitute the modern body of technical knowledge' (Kuhn 1996, p. 140). In a different way, it means that the paradigm provides the identity of a particular group of scientists. Problematization of the 
paradigm would summon an identity crisis, whereas problematization within the paradigm is business as usual, strengthening the group identity.

\subsection{Revolutionary developments}

Kuhn refers to paradigmatic change in two ways. The first is located in the environment (here: the object of study) and consists of what Kuhn refers to as 'anomalies' (1996, p. 52). These are (natural) phenomena that resist problematization within the framework that the paradigm prescribes. When these anomalies persist, they can lead to a crisis within the community challenging the validity of the paradigm. The awareness of an anomaly is the recognition that 'nature has violated the paradigm-induced expectations that govern normal science' (Kuhn 1996, p. 52-53). The question that emerges from the anomaly demands a new vocabulary as well as concepts in order to analyse the anomaly in a way that fits the paradigm, which, at the same time, may imply adjusting the paradigm.

The other lies in the subsequent awareness of the failure of existing theoretical rules. The search for new rules takes place in a situation of crisis where new competing theories emerge, resulting in a plethora of ideas, leading to the loss of status of the paradigm. Indeed, Kuhn considers crisis to be a necessary condition for scientific progress and the emergence of paradigmatic shifts. A consequence of this line of reasoning is that paradigms are per definition incommensurable (Kuhn 1996, p. 148); paradigms are neither superior nor inferior; a new paradigm is different.

Kuhn's choice to refer to 'revolution' indicates, arguably, that it is not solely logical and rational argument and solid proof that convinces the community of entering a new mode of thought. Although they are necessary conditions, they are insufficient. 'Revolution' also expresses a (non-rational) belief in the new paradigm. To this end, scientific revolutions are akin to political revolutions (Preston 2008, p. 52). Indeed, Kuhn draws the parallel explicitly when he sources a political revolution in a particular segment of the political being dissatisfied in the way institutions fail to address societal problems and this segment aims, through revolution, 'to change (...) institutions in ways that those institutions themselves prohibit' (1996, p. 93).

A paradigmatic shift cannot be tested by reference to some higher standard but must assert itself as superior through persuasion, if at all. If the proponents of a new paradigm succeed in convincing the community or at least a large segment of it, a paradigmatic shift will take place. This shift cannot be forced (contrary to a political revolution) and, indeed, should not be forced as it would undo the power of how science is done.

It suggests that paradigms have a normative and a cognitive function. They force us to change our outlook and, hence, how we perceive both (natural) phenomena and their consequences. The proponents of the old and the new paradigm operate 'in different worlds' (Kuhn 1996, p. 150). Indeed, 'what a man sees depends both upon what he looks at and also upon what his previous visual conceptual experi- 
ence has taught him to see' (Kuhn 1996, p. 113). A paradigmatic shift amounts to a 'Gestalt-switch' that leads not only to changes in world views but also to worldchanges, as also observed by Preston (2008, p. 63) and Cotterrell (1995, p. 46). It refers to the idea that there is no objective language of observation - all observation takes place from a particular paradigm. Scientific discovery, then, leads to progress but Kuhn interprets progress not as the accumulation or expansion of knowledge of the field to a final point. Revolutions cause the exchange of knowledge (and the older knowledge is subsequently lost to new students). Hence, paradigmatic change does not bring us closer to the truth. ${ }^{5}$ Kuhn prefers to see the revolutionary process of science as evolutionary. Like Darwin's submission that complex organisms 'were products of a process that moved from primitive beginning toward no goal' (Kuhn 1996, p. 172). ${ }^{6}$

\section{Kuhn outside the natural sciences}

Since the publication of The Structure, the question has arisen to what extent the Kuhnian model is useful for the social sciences and the humanities. Kuhn himself thought it unsuitable for the social sciences, struck as he was by the 'number and extent of the overt disagreements between social scientists about the nature of legitimate scientific problems and methods' (1996, p. x). Others, such as Dogan (2000, p. 1-2), suggest that the social sciences do not or cannot have a paradigm as they engage in the construction of 'unverifiable theories'. ${ }^{7}$ Cotterrell suggests that Kuhn would argue that in the field of law there could be a 'disciplinary effect' rather than a 'full disciplinary matrix' or paradigm (1995, p. 46). What Cotterrell means is that in fields such as law, Kuhn offers no answer to what unifies such a field as 'there are no objective tests of what counts as a discipline since each disciplinary field has its own unique discursive practice' and, relying on Foucault, Cotterrell further argues that fields such as law are 'structured by their direct relevance to particular configurations of power in society' (Cotterrell 1995, p. 46).

I would agree with these positions when we consider the nature of social scientific research or research in the humanities considering that theories there are descriptive and evaluative rather than verifiable by means of established instruments of verification: testing, experiments, etc. And, indeed, modern law is configured through power relations, considering its main author: the state. Nevertheless, Kuhn can be deemed relevant in another way. It allows for a reflexive attitude towards legal research and education, law and power (Campbell 1974, as discussed by Cotterrell 1995, p. 53-54). One reason is that a paradigm, with its particular tools of observation, analysis, interpretation, and argumentation can

5 It is here, perhaps, that Kuhn and Popper coincide, and that there is no such thing as 'absolute truth'; see also Webb 2006.

6 See Cotterrell for a critique on this notion of knowledge advancement (1995, p. 47).

7 What can be said is, following Webb (2006, p. 94-95), that natural science provided a 'foundation for a whole rationalist epistemology, that shaped both the emerging social sciences, and, by the mid-nineteenth century, the attempts to create a rational science of law'. 
be seen as providing a means to make sense of social events and developments to which law responds. It allows them to be ordered. A paradigmatic sketch of legal research, then, would allow the analysis of a particular legal ordering of social interaction on the basis of certain beliefs, values, and techniques and as the type of social interaction differs in time and place, so does the ordering. A paradigmatic sketch of legal research allows for the proper analysis of legal responses by taking note of law's environment (society) that produces facts, events, and developments. It may not be that a paradigm can be formulated but the 'paradigmatic thought process' enables a means of self-observation when engaged in legal research against the background of societal structures.

Furthermore, the basic elements, such as the practice of normal science, the processes of initiation and ritualization and revolutionary developments, are elements with which a legal research community can be described also. Indeed, as legal scholars we tend to engage in 'normal' research, following and analysing what happens in practice: case law and legislation, making sense of them within a particular methodological frame of reference. And one does so from different perspectives or schools of thought ('unverifiable theories'), i.e., law and society, law and economics, critical legal studies, doctrinal theory, etc. (Vranken 2012). They differ in their perspective but, I suggest, agree on certain basic (methodological) assumptions (which will be addressed below). The curriculum at law schools emulates this and students are taught and learn the law unreflectively, taking the assumptions (the beliefs, values and techniques) of modern law and legal research for granted.

Third, this article does not attempt to describe a revolution in legal research but seeks to describe a reflexive view on the frame of reference of modern legal research. I would like to show that there is a 'single orthodoxy' of normal research, centred on methodological nationalism, feeding certain assumptions about modern law. To make this explicit, I take as my point of departure the position that law serves society in one way or the other - or at least relates to society - and to understand law and its functions, we must understand society. This does not mean that there is no place for 'traditional' doctrinal research of law itself, devoid of context, which remains an important and worthwhile enterprise in itself. The point is that to take a contextualized view on law, allows for a reflexive analysis of law, making better visible when and why law struggles with problems it seeks to address. It allows for the description of the so-called Kuhnian anomalies and to understand why they are anomalies.

In doing so, I resort to a theoretical understanding of contemporary society inspired and guided by social theory. ('Fidelity to context' at a high(er) level of abstraction (Selznick 2003). ${ }^{8}$ ) I draw inspiration from the theory of reflexive modernization, as formulated by Ulrich Beck and in particular to the distinction

8 Even though context may be boundless, it does not mean that a theoretical understanding of society is useless so long one considers this understanding as an ongoing process; cf. Cotterrell 1995, p. 287. 
Beck makes between methodological nationalism and a more transnational or cosmopolitan outlook. ${ }^{9}$

\section{$4 \quad$ Normal legal research ${ }^{10}$}

Within the Kuhnian structure of thought, scientists are engaged in 'normal' research. Legal scholars are engaged in 'normal legal research'. They too solve puzzles - the outcome of puzzles solved by practitioners. Both puzzles relate to the function of modern law: its conflict-resolving (and problem-preventing) potential through the attribution of responsibilities based on rules, informed by reason. Arguably, this belief is shared among practitioners of law and legal researchers alike. It is this potential that drives legal practice and research. Indeed, legal research is predominantly concerned with analysing this potential and its productions at different levels. This potential can be located, initially, at three levels (Francot \& De Vries 2006).

\subsection{Three levels of puzzle solving}

The base line level upon which the problem-solving potential of law operates (and is studied) is by reference to incidents: a constellation of facts that is presented as a conflict between individual social actors. It involves, for example, an unfair dismissal or a dispute over land. The persons involved resort to a court to resolve the dispute by means of obtaining an authoritative decision that can be enforced. This decision may become part of the law and subject to research. A research question may relate to how the decision has applied the rules and fits the system of that particular area of the law. The second, higher, level is where these incidents are abstracted to the level of structures. Thus, a dispute about the unfair dismissal of a pregnant worker is placed within the wider structure of equal treatment of men and women on the work floor. In other words, the problem is no longer a dispute between individual actors but demands an answer in more general terms as it is perceived as a societal problem, i.e., legal rules are laid down in legislation or precedent (or a series of precedents) and studied in isolation as a doctrine. It is obvious that the two levels are communicating vessels: a decision

9 One reason to make this choice lies in the compelling way Beck is able to describe the structure of contemporary society and the changes that take place within the structure as well as his prescription as to how these changes ought to be researched and addressed, pleading for a reflexive attitude. Furthermore, it cannot be denied that his theory of reflexive modernization appeals to many other scholars and practitioners, in a variety of disciplines, considering how Beck's work is received. (This does not discharge us from 'using' the theory critically.) Indeed, the acclaim for, and commentary upon, his 1986 Risikogesellschaft causes it to be considered a modern classic; see, for example, Mythen 2004, Hudson 2003, and Steele 2004. (Such a choice, which could be argued to be an irrational or even arbitrary choice, is part of any research paradigm, according to Kuhn (1996, p. 148).)

10 It must be said that much of what is written in subsequent paragraphs about first and second modernity, has appeared in similar or different versions in different previously published articles; see, most notably Francot \& De Vries (2009) Francot \& De Vries (2008) and Francot \& De Vries (2011). 
by a court is based on general rules usually laid down in legislation (or other, often higher case law), whereas such a decision may also pave the way for new legislation or for amending existing legislation or indeed, distinguishing or creating precedent.

There is another level upon which law is studied to try understanding its problem-resolving potential. At this level, we require insight in law as a system. It can be as a system in its own right, for example, law as a (national) civil law system or common law system. Here research is focused on how law is organized internally, what its sources are, how decisions come about, its history, etc. It can also be studied as a social system where we ask questions as to how it responds to problems at an even higher level of abstraction. Thus, where unfair dismissal was abstracted to the problem of equal treatment at the work floor, this problem can be abstracted as a problem that concerns society as a whole: how can law contribute to equality when it is considered to be a fundamental (moral) organizing principle of society? In respect of legal research this level is the domain of legal theory and jurisprudence, and in practice it may be visible in key decisions by higher courts or fundamental rules about society, laid down in a constitutional document or international treaties.

Most legal research concerns the analysis of that what happens in practice. In other words, most research concerns the analysis of case law and legislation. More abstractly: legal research has as its object predominantly that what the problem-solving potential of law has produced and how these productions fit the system from which they are derived. It makes legal research a practice-embedded theory as it follows practice and emulates its methodology.

\subsection{Which problems? Modern problems}

There is a tacit understanding that the problem-solving potential of law is geared towards specific problems bound in time and place. Hence, modern law is geared towards modern problems. Making these problems and their context explicit contributes to a fuller description of the frame of reference of modern legal research as they disclose its basic assumptions.

Modernity itself can be described in a paradigmatic way. The fundamental belief of modernity lies in the notion of Progress through Reason of which the Enlightenment is the illuminative political, cultural, scientific, and historical insignia. The belief in Progress fuelled the twin processes of industrialization and democratization addressing the twin problems of scarcity and tradition, culminating in the industrial society (Beck 1992, ch. 1). These processes were both situated in and circumscribed by the modern nation-state. The process of industrialization is concerned with the production of wealth through the technological application of science and scientific discoveries. The process of democratization served, among many other things, to facilitate and regulate the production of wealth, its just distribution, and the emancipation of humans as autonomous individuals, freeing them from tradition and subordination. 
Positive law made important contributions in respect of the efficient production and distribution of wealth. It facilitated and regulated production and distribution through rules based on concepts such as the freedom to contract, ownership and possession, legal personality and liability. Law reflects and gives voice to the developing (economic) liberal theory of the time. This can also be observed in the role of the state. This role was, initially, a restricted one and concerned with allowing the market to function and rights (to life, liberty and property) to be protected from internal and external threats. Indeed, law served to improve the position of the autonomous individual to which the recognition of civil and political rights attest but it did so in a formal way. Like the market, the state too was subject to regulation, encapsulated in the modern notions of the rule of law and democracy. The sharp distinction between the private and the public, at least in Continental Europe, resonates in the two main bodies of modern law: private and public law. The concept of state sovereignty was the guiding force of the development of modern international law (Held 2002, p. 3-4).

The distinction between the public and the private started to blur as a result of what is termed in the Netherlands the 'Sociale Quaestie' or, in Marxists terms, 'Die Verelendung'. It denotes the extreme poverty and social immobility of the working classes across Europe during the late era of modernity. This situation gave rise eventually to social democracy and culminated in the Welfare State. ${ }^{11}$ Law, here, did not merely codify important concepts of modernity into manageable rules, but was employed as a tool to give shape to society as prescribed by the state. It saw the rise of social-economic rights allowing an effective use of civil and political rights. It saw an extensive system of social security based on law as well as the introduction of many legal measures that sought to protect the weaker party in all kinds of contractual agreements. In more abstract terms, one saw the juridification of an ever increasing variety of social interaction with an aim to mould social interaction in a 'designed society', based upon rules - an attempt, perhaps, to juridify the context. The early developments in respect of European cooperation can also be understood in this way.

\subsection{Legal research and its assumptions}

Understanding modern society, of which the above is but a mere coarse-grained snapshot, suggests considering society as based upon the fundamental belief of Progress through Reason, culminating in the belief of the Machbarkeit of society by the state, guided by certain fundamental organising principles, such as democracy, rule of law, freedom, equality, solidarity, sovereignty, capitalism, etc. ${ }^{12}$

Modern legal research is geared towards studying law's problem solving potential and its productions and it does so predominantly from this modern frame of ref-

11 This phase is deemed a phase of the first modernity because the production and distribution of wealth remained the central feature.

12 The Rawlsian interpretation would be societies geared towards cooperation for mutual benefit within a given jurisdiction, i.e., nation states circumscribed by the notion of freedom, equality, and difference (Rawls 1973, p. 4). 
erence. Students who are initiated to the study of law are taught this frame of reference unreflectively, if at all, taking as a given the idea of a body of law, based on certain organizing principles, confined within the sphere of the nation state - the jurisdiction in which law is studied. As a consequence, a number of assumptions (the Kuhnian beliefs, values and techniques) are unavoidable and, at least to a high degree, uncontested. These assumptions, I argue, constitute the frame of reference of modern legal research. Without claiming to be exclusive, they refer to (1) the goal and function of law, (2) the sources of law, (3) the 'territory' of law, (4) the relationship between facts and law, (5) the corresponding notion of legal causality, and (6) the overall perspective: methodological nationalism.

\section{- $\quad$ Ad 1}

At the most abstract level, the overall goal of law lies in its contribution to social order or in contemporary social systems theoretical terms: the reduction/transformation of complexity and uncertainty (Luhmann 2004; Francot-Timmermans 2008, p. 115). This contribution translates into the fundamental belief in the problem-solving potential of modern law in respect of the problems of modernity - problems within the processes of industrialization and democratization. Law provides an exclusive framework to deal with these problems.

\section{- $\quad$ Ad 2}

This potential revolves around attributing responsibilities normatively through the application of rules. ${ }^{13}$ Hence, modern law is a general rule-based legal system and the rules are normatively informed based on reason and its object: Progress. What makes legal rules different from other types of rules (ethical, moral and social rules) lies in who is believed to have the capacity to make (and enforce) legal rules and how they must be made (cf. Hart 1994). Indeed, the sources of positive law are deemed uncontroversial, with the state being the dominant actor (legislation) including an independent judiciary (case law) and in addition but to a lesser extent, customary law, unwritten legal principles and scholarly writing (doctrine).

\section{- $\quad A d 3$}

It follows that law enjoys its authoritative status because of its organizational back-up, embedded within the nation state. At the same time, the nation state delineates the problem-solving potential, geared predominantly to problems that are generated from within the nation state. Thus, modern law is by implication national, or state, law - there is a 'stable political geography' (West 1978, p. 230).This can even be said of most of international law which is law that is pro-

13 Indeed, as Varga (1999, p. 22) announces: 'in law we usually think of their existence [norms] as obvious, although they are only paradigmatic in modern formal legal arrangements'. Furthermore, legal positivism has contributed to our conception of law as existing in written rules of a particular authoritative status (see Varga 1999, p. 28 but see also Dworkin's conception of Hart in Dworkin 1978, p. 14-46). 
duced by nation states among themselves and exists in the consolidation of agreements between them into rules (written or unwritten).

\section{- $\quad \operatorname{Ad} 4$}

Law regards facts. What I mean here is that law stems from facts and applies to facts. An important aspect of legal craftsmanship lies in the analysis of the constellation of facts that makes up the conflict or problem and to transform this constellation of facts into a legally relevant question that fits the legal frame of reference. Hence, applying law implies the reduction of facts to a legally manageable fiction. Indeed, 'the circumstances of the case' determine the relevant legal rules to be applied, while the lawyer determines these circumstances - selects the facts - by reference to these rules.

\section{- $\operatorname{Ad} 5$}

An important aspect of law lies in its contribution to attribute responsibility through legal concepts such as rights, duties, liabilities, etc. Responsibility is attributed on the basis of the interpretation of a constellation of facts and the interpretative structure is predominantly an 'if ... then ...' structure (FrancotTimmermans, 2008, p. 93, referring to Luhmann, 1997, p. 197); a linear structure of causality. The facts involve actions (or omissions) by legal actors or agents. What they do (or do not) is what determines causality and, hence, the attribution (or not) of responsibility. To put it mores simple: if an actor A can (not) be said to have caused $\mathrm{X}$, then responsibility can (not) be attributed. In doing so it replicates the linear system of first modernity (Lash, 2003).

\section{- $\quad$ Ad 6}

Modern law and its study are firmly embedded within the nation state as an exclusive, all-encompassing social unit. It does not only denote a particular jurisdiction and authorship but entails also a mode of observation, analysis, argumentation and interpretation; a particular mode of research. It denotes the idea, according to Beck, that "modern society" and "modern politics" [but also modern law (UdV)] can only be organized in the form of national states' (2006, p. 24). It is a 'national outlook' that determines the modern researcher's perspective and this breaks down in a number of broader presumptions, including a territorial understanding of society, a society subordinated to the state, a world image determined along the axis national-international and the fallacy to universalize the particular: universalizing national society; read: modern Western society (Beck 2006, p. 27-33).

\section{Modern law's anomalies}

Insofar legal research is geared towards studying problems that fit the frame of reference, these can be accounted for in the usual way and legal research (at the level of incidents and structures) emulates legal practice in its case study method, applying the sequential tools of observation, analysis, argumentation and inter- 
pretation (Campbell 1974, p. 22; Wallace 1978, p. 234). It is business as usual, so to speak. However, when problems take place on the level of societal structures, the fundamental belief in law's potential are challenged; these developments can not be accounted for but become 'Kuhnian anomalies'. These anomalies can be explained through a reflexive attitude towards law's assumptions and this can be done if the object of study is not limited to law itself but, where and when these anomalies arise, also includes its environment to make sense of these structural problems; to understand where these facts come from, what brought it about that these facts appeared? Social theory is a means, complementary to legal theory and knowledge of the law, to make sense of the new problems modern law is confronted with.

A theoretical distinction, as Beck does, of the notion of modernity into two phases, first and second modernity, makes visible how structural changes impact upon law and legal research, showing the limitations of the aforementioned assumptions. ${ }^{14}$ These changes are constituted by the side effects of first modernity's successes and characterize second modernity. It may be that the assumptions remain valid, but no longer exclusively so, as they struggle with these side effects, as if they were anomalies. As much as we are accustomed to think of law as having a problem-resolving potential, so do we think of law as distributing or attributing responsibility, which is the focus of much legal research. Luhmann (1994, p. 139) already pointed to the problem-generating potential of law.

By way of illustration, Veitch (2007, p. 1), in an insightful legal analysis, shows that law and legal institutions, while distributing responsibility, are also 'centrally involved in organising irresponsibility'. The kernel of his analysis is that there exists an asymmetry between the production of suffering (through violence, large scale environmental damage, etc.) and legal responsibility for it through the operation of legal mechanisms, such as its modes of categorization, normalization of behaviour (lawful behaviour is deemed normal despite damage caused and, hence, remains mostly unquestioned), role differentiation (law defining the extent of my responsibility, for example, as shareholder of a major oil company destructing the environment) and as a result the fragmentation of responsibility. It follows that law is able to create its own fiction of responsibility. Another example, that illustrates this point, is provided by Pogge. In the second edition of his World Poverty and Human Rights (2008, 222-256), he questions the lack of access to medical care, and medicine in particular, by people in Africa. An explanation is found in the legal regime of patents that allows an exclusive claim on intellectual property in (newly developed) medicine and hence, a monopoly, so to speak, of the exploitation of this medicine. The regime remains to a large extent unquestioned, as it is said to drive innovation and development in health care. That needed medicine is subsequently not developed or inaccessible due to high costs remains a mere side effect of the regime, which is regarded as 'normal', as it is legal. It calls, as Pogge does (and Veitch problematizes in terms of (ir)responsibility), exactly

To be sure, differentiating between first and second modernity allows differentiation between types of processes and developments that are nonetheless interlinked. 
because of its 'normality', for a reflexive approach: are alternatives possible considering the injustice created by the law?

It also impacts upon how we think about the role of the state, an entity which is under siege by processes of globalization. These globalization processes call for a new perspective and methodology, incorporating the national outlook into something broader, a more transcending, cosmopolitan outlook (Beck 2006). This perspective would open up our vision to the side-effects of real global interaction and interdependency, which lay outside state/society. The vision annuls the equation of state and society. The side effects exist in ecological risks, economic crises, global injustice, and terrorist threat. These side effects give rise to new political conflicts that cannot be addressed by the existing institutional framework. Beck (2006, p. 23):

'In world risk society - this is my thesis - at least, the question concerning the causes and agencies of global threats sparks new political conflicts, which in turn promote an institutional cosmopolitanism in struggles over definitions and jurisdictions. [Solutions]can scarcely be envisaged without new global institutions and rules, and hence without a certain degree of convergence.'

Furthermore, strict adherence to the modern notion of causality may no longer prove to be effective or possible for distributing responsibility when chains between causes and effects become longer, more global and more diffuse. These aspects reveal the possibility of a new reflexive paradigmatic view on legal research.

\section{Changing conditions: the uncertainty problem}

Uncertainty - as perhaps the central problem of law - must continually be remapped; it must be redefined in order to allow research that in turn contributes to the formulation of new law or least to find out when law is useful. Although uncertainty has become immanently global and transnational, what is the same, is that it remains revolving around the Lockean trinity of 'life, liberty and property', maintaining, indeed exacerbating, inequality and this time on a global level.

The changing nature of uncertainty is only partially present within the modern frame of reference of legal research. The frame of reference uses the environment of law, society, as a given - not necessarily static but only changing in terms of incidents (facts!) and if and when structures are concerned, only on the level or in terms of the nation state (global aspects are 'localized'), only in terms of 'if ... then ...' causalities, only in terms of wealth distribution, etc. Indeed, the modern frame of reference holds on to the assumptions, as questioning them could lead to an internal crisis about the unity of modern law. But exactly this questioning is what is demanded, the courage of legal research to confront itself with its assumptions. 
It points to a fourth level of legal research (in addition to the levels of incident, structure and law as a system, as discussed above) which places legal research also at the level of society as a system, demanding a social theoretical perspective to law and legal research (Francot \& De Vries 2006). This level of self-confrontation lies at the heart of a reflexive paradigmatic view on legal research (and emulates Beck's plea for second modernity going through a process of reflexive modernization).

A reflexive paradigmatic view takes the changing conditions into account without letting go of the national or local conditions that are and remain in a certain sense the 'Unterbau' of those global developments. Furthermore, such a view is able to account for the limitation of the aforementioned assumptions, making these limitations explicit and visible.

To be sure, the reflexive paradigmatic view offers one perspective on legal research and revolves around the interplay between law and society in terms of uncertainty (rather than in terms of points of departure or principles). This perspective allows for a critical potential but demands a trans- or cross-disciplinary approach (Karanika-Murray \& Wiesemes 2009). ${ }^{15}$ In doing so, it must have regard to the 'global condition'.

Reflexive modernization exists in society's confrontation with its foundations and organizational structures and principles. This confrontation has methodological consequences. Methodological nationalism no longer suffices if one takes serious the problems of the global condition that transcends the national-international axis. A national outlook alone is not sufficient but must be incorporated into an encompassing and transcending outlook, which Beck denotes as cosmopolitan, demanding its own cosmopolitan methodology. The main feature of this methodology lies in the awareness and reconsideration of one's position of observation with an aim to be informative about how to employ, as a scholar, the sequential tools of observation, analysis, interpretation and argumentation. In respect of the current frame of reference of legal research, it means taking issue with a structural rather than an incidental approach to the no longer tacit side effects of modernity's successes. It means a more integrated approach to understanding the correlation between wealth production and the side effects it causes (which Beck (1992) denotes as 'modern risks'); it means a multilateral approach that breaks through the traditional concepts of sovereignty involving other social actors than nation states and international organizations; it means taking serious issues with poverty and new social positions at the global level - particular in those areas where one suffers the twin problem of both scarcity and the side effects of wealth production (Pogge 2008); it demands novel categories of causality and responsibility; it demands new ways to deal with loss and damage. In all, it

15 Such an approach as well as an analysis of the practical, sequential tools of the paradigm are subject of another article and are outside the scope of this article. Furthermore, and which demands further study, the paradigm integrates the internal and external approach to studying law, see for the distinction Tamanaha 1996. 
demands taking issue, reflexively, with the above mentioned assumptions of the current frame of reference of legal research.

\section{Conclusion}

As law serves society, understanding law also demands an understanding of society in a given time and place, here: modern society being in a state of flux and structural change.

When developments take place on the level of social structures, the foundation and assumptions of legal research are challenged; these developments can at first not be accounted for but become anomalies instead, in the Kuhnian way. When the modern frame of reference takes issue with its own assumptions, by taking a reflexive attitude and lifting itself to a higher level of abstraction it can account for these anomalies. It allows for what Cotterrell (1995, p. 48) refers to as the 'confrontation between disciplines', challenging 'the mechanisms sustaining the disciplinary effect of these fields', opening up the limitations of the assumptions. More fundamental, paradigmatic thinking enables one to take issue with law's paradox, that is: to take issue with the question whether it is lawful to apply the distinction between lawful and unlawful, against the background of new social theoretical ways to perceive the world (Luhmann, 2004, p. 101). The paradigm does not deny or reject the paradox but is able to take issue with it because it is able to take issue with changes at the structural level of society: what was lawful may be (or ought to be) unlawful. The paradigm can, furthermore, add the third dimension and posit the differentiation between lawful and unlawful against justice and this time at the global level. ${ }^{16}$

The formulation of such a paradigmatic view seems inevitable as structural changes in society confront law with unprecedented and unexpected problems and legal scholars with the limits of (modern) law. Illustrative are ecological uncertainties as a result of industrial activity (risks), including the impact of climate change. Other examples refer to new moral consequences of technological innovations in the area of the health sciences and how legal responses, such as the precautionary principle, impact on values like legality, global justice and solidarity (De Vries \& Francot-Timmermans 2011). The essence of legal research, arguably, is to detect these changes and make them explicit and much work is being conducted here already.

It is with broad brush strokes that I sketched the contours of a paradigmatic view on legal research. Much remains unresolved and demands study in later work, for example, how such a paradigmatic view can contribute to understand the problematization of existing legal theories with an aim of further theorization in law, for example in criminal law and the notion of mens rea (Greene \& Cohen 2004). This would include changes in legal education and the curriculum to teach stu- 
dents how to confront the assumptions and their limitations. A first step towards such change is towards integrating legal research and legal education: to teach what we research rather than to teach that what is written in textbooks. Further research should also include analysing the notion of contextualization, allowing for a measure of transdisciplinarity in the sense that legal research must at times resort to other domains of knowledge to preserve its integrity, ${ }^{17}$ when confronted with what it perceives as an anomaly.

\section{References}

\section{Bauman 2000}

Zygmunt Bauman, Liquid Modernity, Cambridge: Polity 2000.

\section{Beck 1992}

Ulrich Beck, Risk Society - Towards a New Modernity, London: Sage, 1992. (German original: Risikogesellschaft - Auf dem Weg in eine andere Moderne, Frankfurt am Main: Suhrkamp 1986.)

\section{Beck 1997}

Ulrich Beck, Reinvention of Politics, Cambridge; Polity Press 1997. (German original: Die Erfindung des Politischen, Frankfurt am Main: Suhrkamp 1993.)

\section{Beck 1999}

Ulrich Beck, World Risk Society, Cambridge; Polity Press 1999.

\section{Beck 2006}

Ulrich Beck, Cosmopolitan Vision, Cambridge: Polity 2006. (German original: Der kosmopolitische Blick oder; Krieg ist Frieden, Frankfurt am Main: Suhrkamp 2004.)

\section{Beck \& Grande 2004}

Ulrich Beck \& Edgar Grande, Das kosmopolitische Europa, Frankfurt am Main: Suhrkamp 2004.

\section{Campbell 1974}

Colin Campbell, 'Legal Thought and Juristic Values', British Journal of Law and Society 1974, p. 13-30.

\section{Cohen 2002}

Jean L. Cohen, Regulating Intimacy: A New Legal Paradigm, Princeton/Oxford: Princeton University Press 2002.

\section{Cotterrell 1995}

Roger Cotterrell, Law's Community - Legal Theory in Sociological Perspective, Oxford: Clarendon Press 1995.

\section{Dogan 2000}

M. Dogan, 'Are there Paradigms in the Social Sciences?', Revista de Cercetare Sociale 2000-1/2, p. 3-9.

\section{Dworkin 1978}

Ronald Dworkin, Taking Rights Seriously, London: Duckworth (new impression) 1978.

17 Without this necessarily leading to the integration of that knowledge; see Nelken 1998, p. 410, stressing that 'the attempt to deploy social insights so as to help law's reflexivity requires us to pay more rather than less attention to their disciplinary and discursive connections'. See also Webb 2006, citing Luhmann 2004. Indeed, at a higher level of abstraction it demands a reflexive view on knowledge itself. 


\section{Francot-Timmermans 2008}

L.M.A. Francot-Timmermans, Normativity's Re-Entry. Niklas Luhmann's Social Systems Theory: Society and Law, Nijmegen: Wolf Legal Publishers 2008.

\section{Francot \& De Vries 2006}

Lyana Francot \& Bald de Vries, 'Legal Education Re-Enchanted', European Journal of Legal Education 2006, p. 3-20.

\section{Francot \& De Vries 2008}

Lyana M.A. Francot \& Ubaldus R.M.T. de Vries, 'Normativity in the Second Modernity', Rechtstheorie 2008, p. 477-494 (actually published in 2009).

\section{Francot \& De Vries 2009}

Lyana Francot \& Bald de Vries, 'No Way Out - Contracting About Modern Risks', ARSP (Archiv für Rechts- und Sozialphilosophie) 2009, p. 199-215.

\section{Francot \& De Vries 2011}

Lyana Francot \& Ubaldus de Vries, 'Justice Unbound - Responsibility in the Second Modernity', in: Ubaldus de Vries \& Lyana Francot (eds.), Law's Environment: Critical Legal Perspectives, The Hague: Eleven International Publishers, 2011, p. 201-220.

\section{Fuller 2003}

Steve Fuller, Kuhn v. Popper - The Struggle for the Soul of Science, Cambridge: Icon Books (reprint).

\section{Greene \& Cohen 2004}

J. Greene \& J. Cohen, 'For the Law, Neuroscience Changes Nothing and Everything', Philosophical Transactions of the Royal Society B 2004, p. 1775-1785.

\section{Hart 1994}

H.L.A. Hart, The Concept of Law (2nd ed.), Oxford: Oxford University Press 1994.

\section{Held 2002}

David Held, 'Law of States, Law of Peoples: Three Models of Sovereignty', Legal Theory 2002, p. 1-44

\section{Hol \& Ippel 1997}

Ton Hol \& Pieter Ippel, 'Grenzeloze verantwoordelijkheid? Recht en moraal in de risicomaatschappij: verband en verschil' (Limitless Responsibility? Law and Morality in the Risk Society: Differences and Overlappings), in: B. Hessel et al. (eds.), Het recht over de schutting. De rol van de jurist bij interdisciplinair onderzoek, Nijmegen: Ars Aequi Libri, p. 27-47.

\section{Hudson 2003}

Barbara Hudson, Justice in the Risk Society, London: Sage 2003.

\section{Karanika-Murray \& Wieseme 2009}

M. Karanika-Murray \& R. Wieseme (eds.), Exploring Avenues to Interdisciplinary Research, Nottingham: Nottingham University Press 2009.

\section{Kronman 1995}

Anthony K. Kronman, The Lost Lawyer - Failing Ideals of the Legal Profession, Cambridge/London: Belknap 1995.

\section{Kuhn 1996}

Thomas S. Kuhn, The Structure of Scientific Revolutions (3rd ed.), Chicago: University of Chicago Press 1996.

\section{Lash 2003}

Scott Lash, 'Reflexivity as Non-linearity', Theory, Culture and Society 2003-2, p. 49-57.

Luhmann 1994

Niklas Luhmann, Das Recht der Gesellschaft, Frankfurt am Main: Suhrkamp 1994.

\section{Luhmann 2004}

Niklas Luhmann, Law as a Social System, Oxford: Oxford University Press 2004. 


\section{Mythen 2004}

Gabe Mythen, Ulrich Beck - A Critical Introduction to the Risk Society, London: Pluto Press 2004.

\section{Nelken 1998}

David Nelken, 'Blinding Insights? The Limits of a Reflexive Sociology of Law', Journal of Law and Society 1998, p. 407-426.

\section{Pogge 2008}

Thomas Pogge, World Poverty and Human Rights (2nd ed.), Cambridge: Polity 2008.

\section{Popper 2002}

Karl Popper, The Logic of Scientific Discovery, London/New York: Routledge. (German original: Logik der Forschung, Wien: Springer, 1935.)

\section{Preston 2008}

John Preston, Kuhn's The Structure of Scientific Revolutions, London/New York: Continuum 2008.

\section{Rawls 1973}

John Rawls, A Theory of Justice, Oxford: Oxford University Press 1973.

\section{Selznick 2003}

Philip Selznick, 'Law in Context, Fidelity to Context', Journal of Law and Society 2003, p. 177-186, <http://escholarship.org/uc/item/5mp0w9r9> (last visited: 15 October 2010).

\section{Steele 2004}

Jenny Steele, Risks and Legal Theory, Oxford: Hart Publishing 2004.

\section{Tamanaha 1996}

Brian Z. Tamanaha, 'The Internal/External Distinction and the Notion of a "Practice" in Legal Theory and Sociololegal Studies', Law \& Society Review 1996, p. 163-204.

\section{Taylor 2004}

Charles Taylor, Modern Social Imaginaries, Durham/London: Duke University Press 2004.

\section{Turner 1987}

Bryan S. Turner, Medical Power and Social Knowledge. London: Sage 1987.

\section{Varga 1999}

Csaba Varga, 'Paradigms of Legal Thinking', Acta Juridica Hungarica 1999, p. 19-41.

\section{Veitch 2007}

Scott Veitch, Law and Irresponsibility, Oxon: Routledge-Cavendishop (Glasshouse) 2007.

\section{Vranken 2012}

J.B.M. Vranken, 'Exciting Times for Legal Scholarship', Law and Method 2012-2, p. 42-62.

\section{De Vries \& Francot 2009}

Bald de Vries \& Lyana Francot, 'The Legal Method Reconsidered: Contextual Legal Research from an Interdisciplinary Perspective - towards Developing a New Paradigm', in: M. Karanika-Murray \& R. Wieseme (eds.), Exploring Avenues to Interdisciplinary Research, Nottingham: Nottingham University Press 2009, p. 167-179.

\section{De Vries \& Francot-Timmermans 2011}

Bald de Vries \& L. Francot-Timmermans, 'As Good as It Gets: On Risk, Legality and the Precautionary Principle', in: L. Besselink, F. Pennings \& S. Prechal (eds.), The Eclipse of the Legality Principle in the European Union, Alphen aan den Rijn: Kluwer Law International 2011, p. 11-34.

Wallace 1978 
Jude Wallace, 'Current Problems in Legal Theory', Monash University Law Review 1978-4, p. 230-250.

Webb 2006

Julian Webb, 'When "Law and Sociology" Is Not Enough: Transdisciplinarity and the Problem of Complexity', in: M. Freeman (ed.), Law and Sociology, Oxford: Oxford University Press 2006, p. 90-107.

West 1978

Jude West (1978) "Current Problems in Legal Theory", Monash University Law Review, Vol. 4 (June 1978), pp. 230-250 